\title{
Temporal progress of teak rust in a tropical area of Tocantins State, Brazil
}

\author{
Nathana Izabela Silva SALES, Evelynne Urzêdo LEÃO, Lucas Caius Moreira do Amaral CORREIA, \\ Chrystian de Assis SIQUEIRA, Gil Rodrigues dos SANTOS* \\ ${ }^{1}$ Universidade Federal do Tocantins, Campus de Gurupi, Rua Badejós, Chácaras 69 a 72, Zona Rural, Caixa Postal 66, CEP 77402970 Gurupi, T0, Brasil. \\ * Corresponding author: gilrsan@mail.uft.edu.br
}

\section{ABSTRACT}

Rust, caused by Olivea neotectonae, stands out as the main teak disease, causing premature defoliation regardless of the tree's growth stage. In this study, we aimed to assess the temporal progress of rust in adult teak plants in southern Tocantins State (Brazil). Both rust incidence and severity were evaluated and the disease progress curves were obtained, adjusting to monomolecular, logistic and Gompertz mathematical models. Data from incidence and severity were correlated with climate variables collected by the agrometeorological station located in the study area. Rust incidence reached $100 \%$ at 98 days after beginning of the evaluations (DBE). The highest severity (equal or above $75 \%$ ) was observed at $147 \mathrm{DBE}$. There was a significant and negative correlation between severity and minimum temperature. The adjustment of the Gompertz model suggests that control measures should be aimed primarily to reduce the rate of disease progress.

KEYWORDS: epidemiology, Tectona grandis, Olivea neotectonae

\section{Progresso temporal da ferrugem da teca em uma área tropical no Estado do Tocantins, Brasil}

RESUMO

A ferrugem, causada por Olivea neotectonae, destaca-se como principal doença da teca, causando desfolha prematura em todos os estádios fenológicos da cultura. O objetivo do estudo foi avaliar o progresso temporal da ferrugem em plantas adultas de teca no sul do Estado do Tocantins. Avaliaram-se a incidência e severidade da ferrugem (escala de notas) e obtiveram-se curvas de progresso da doença, que foram ajustadas aos modelos matemáticos monomolecular, logístico e Gompertz. Correlacionaramse os dados de incidência e severidade com as variáveis climáticas coletadas na estação meteorológica, localizada na região do estudo. A incidência da ferrugem atingiu 100\% aos 98 dias a partir do início das avaliaçóes (DIA). A maior severidade (igual ou acima de 75\%) foi observada aos 147 DIA. Houve correlaçáo negativa e significativa entre severidade e temperatura mínima. O ajuste ao modelo de Gompertz sugere que medidas de controle devem ser tomadas objetivando reduzir a taxa de progresso da doença.

PALAVRAS-CHAVE: epidemiologia, Tectona grandis, Olivea neotectonae 
Teak (Tectona grandis L.f.) can be affected by a large number of pathogens, with fungi being the most economically significant ones. Among fungal diseases, rust, caused by Olivea neotectonae T.S. Ramakrishnan and K. Ramakrishnan (=Chaconia tectonae T.S. Ramakrishnan and K. Ramakrishnan) stands out as the most important. Rust has been reported in several teak plantations in Brazil, in addition to other countries of Central America, South America, Asia and Oceania (Pieri et al. 2011; Hackbarth et al. 2014).

Rust causes severe and premature defoliation regardless of the tree's growth stage, causing reduction in photosynthetic rate, thus reducing the plants growth rate, and consequently, interfering with wood yield. It can lead to plant death, depending on the age of the plant in which fungal infection occurs. The pathogen spread is favored by the wind in dry periods and requires rainfall or leaf wetness to become established within the planted area. It may also be disseminated through infected plants, since its transmission by seeds seems most unlikely (Gasparotto and Pereira 2013; Pieri et al. 2011).

In Brazil, the knowledge of the epidemiology of diseases occurring in teak plantations is scarce, making it difficult to estimate its potential impact in large forest areas. The epidemiological knowledge is of great importance for the proper development of strategies for disease control (Vale et al. 2004). In this context, the aim of this study was to evaluate the temporal progress of teak rust in an area in the south of the state of Tocantins, in the southeast of the Legal Amazon region.

The study was performed in a teak plantation located in the experimental area of the Federal University of Tocantins, Gurupi, Tocantins State (1 $11^{\circ} 43^{\prime} 45^{\prime \prime}$ S, 49 $44^{\circ}$ '07”W, 278 masl). The predominant climate in the region is of type C2 $\mathrm{wA}^{\prime} \mathrm{a}$ ", with humid to sub-humid weather and moderate water deficit in winter (Thornthwaite 1948). Climatic variables were recorded by an agrometeorological station located in the study region. The assessment area consisted of trees from three to seven years old, planted in spacing of $3.0 \mathrm{~m} \mathrm{x} 2.0 \mathrm{~m}$. Ten trees were randomly chosen and tagged, with the purpose of monitoring the incidence (percentage of leaves with rust) and severity (levels of infection) in each individual. Due to the difficulty in assessing severity on all leaves of a tree, 100 diseased leaves were selected from each tree, in groups of ten from each lower, middle and upper canopy, and from apical, median and basal sections of branches. Each leave was marked, listed and assessed individually.

The disease assessments were carried out weekly, in a total of 29 ratings, in the period from January $30^{\text {th }}$ to August $14^{\text {th }} 2015$. The disease became established through natural infection from an inoculum source that probably was already present in the study area. When first symptoms became evident, some non-marked leaves were collected and brought to the laboratory, in order to carry out the diagnosis (Cabral et al. 2010). Rust incidence was computed taking into account the number of leaves of each tree with rust symptoms related to the total sample, expressed in percentage. The rating scale proposed by Santos et al. (2005) was adopted to asses rust severity, in which: $0=$ healthy plant; $1=$ less than $1 \%$ of leaf area showing disease symptoms; $3=1$ to $5 \% ; 5=6$ to $25 \%$; 7 $=26$ to $50 \% ; 9=$ more than $50 \%$ of leaf area showing disease symptoms. Afterwards, the values obtained for each tree were transformed (average value of the scale) in proportion of leaf area showing disease symptoms (dependent variable), and were plotted versus the time (independent variable) and expressed as disease progress curve, in order to represent the rust progress in the study area. The mathematical models most commonly used in epidemiology were adjusted to the data.

The monomolecular model $x=100\left(1-\left(1-\left(x_{\delta} / 100\right) \exp (-r t)\right)\right.$, the logistic model $x=100 /(1+((100 / x 0)-1) \exp (-r t))$, and the Gompertz model $x=100 \exp \left(\ln \left(x_{0} / 100\right) \exp (-r t)\right)$, in which $x$ represents the severity in percentage at time $t, x_{0}$ is the disease severity in time $\mathrm{t}_{0}$, and $r=$ rate of disease progress for each model, being the time in days (Campbell and Madden 1990; Bergamin Filho 2011). The best fit model was chosen through the highest value of the coefficient of determination $\left(R^{2}\right)$ and the lowest standard deviation for the initial inoculum of the disease $\left(x_{0}\right)$.

A Pearson's correlation analysis was used to correlate observed monthly averages of incidence and severity with climatic variables (precipitation, minimum, maximum and average temperature, and relative humidity), with the significance determined by $F$ test $(\mathrm{P}<0.05)$.

The disease occurred naturally in the trees, being the symptoms identified as small chlorotic punctuations and/or necrosis on the adaxial leaf surface, which corresponded to the beginning of the infection. On the abaxial leaf surface masses of urediniospores of orange color with intense sporulation were observed, which are characteristic signs of the $O$. neotectonae pathogen. The first symptoms became evident seven days after the beginning of the assessment and increased rapidly until the 35 th day (Figure 1). Disease incidence was computed until May, corresponding to 100 days from the beginning of the assessment. Disease incidence increased over time, reaching $100 \%$ of symptomatic leaves at 98 days from the beginning of the assessment, coinciding with periods of higher rainfall and average temperature (monthly average of $26.9^{\circ} \mathrm{C}$ ) (Figure 1). Although it is known that disease progress is directly related to climatic variables, there was no significant correlation of rust incidence with any climatic variable (Table 1).

There was a sharp increase in disease progress during assessment time, with the highest severity being observed at 147 days, when all the leaves displayed severity equal or above $75 \%$ (Figure 2). There was no significant correlation of severity with any climatic variable, except a negative correlation with 


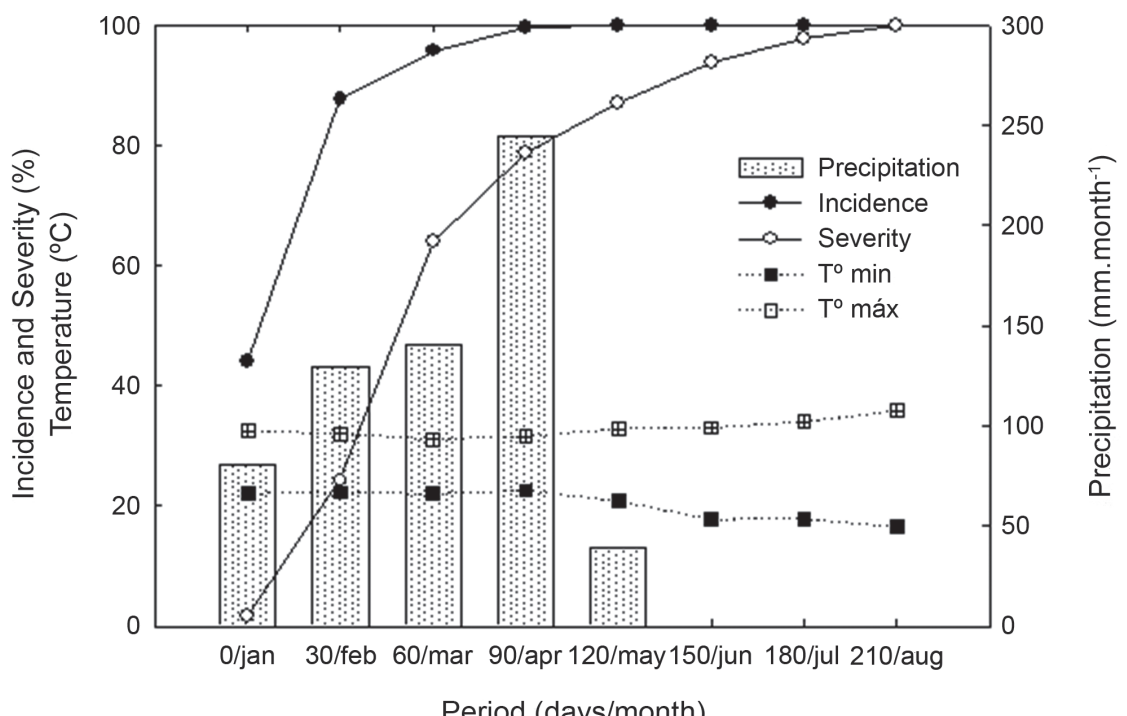

Figure 1. Progress curve of teak rust (Olivea neotectonae) incidence and severity and climate variables at Gurupi, Tocantins, Brazil, from January to August 2015.

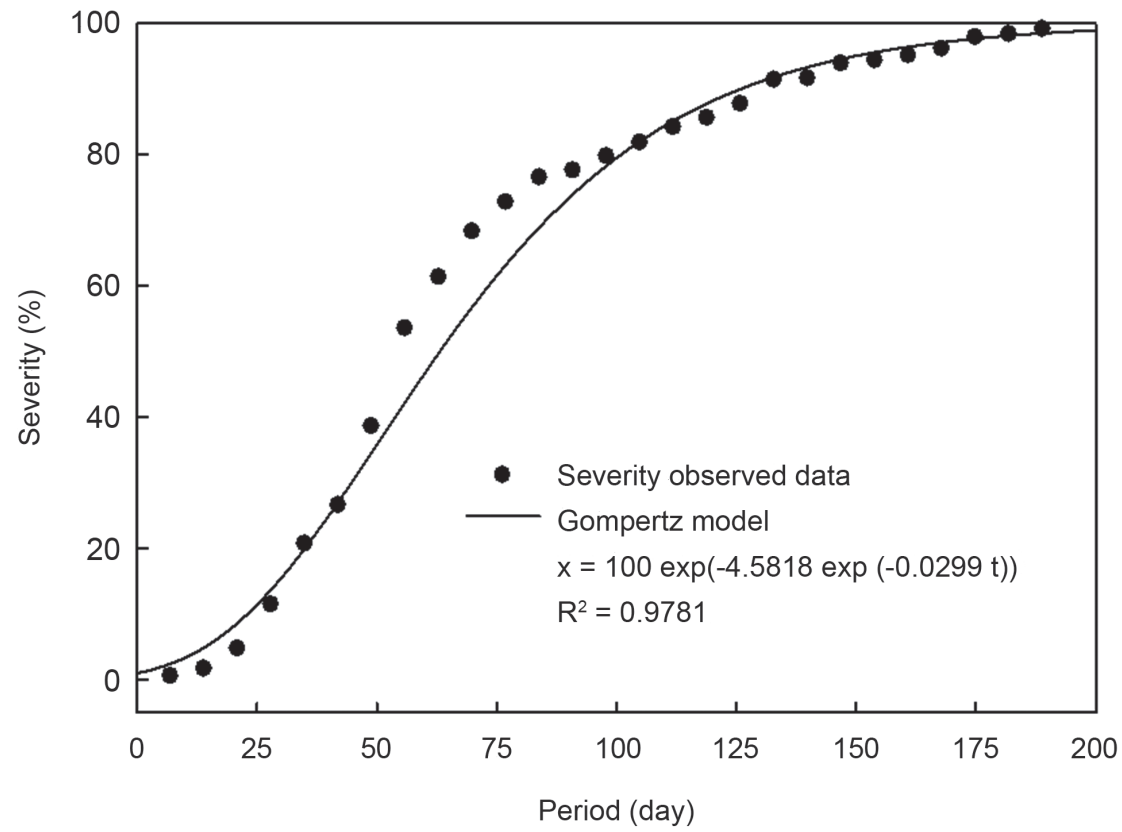

Figure 2. Progress curve of teak rust (Olivea neotectonae) severity with adjustment of the Gompertz model, in the study area of Gurupi, Tocantins, Brazil, from January to August 2015.

Table 1. Correlation coefficients $(r)$ of monthly averages of incidence and severity of teak rust (Olivea neotectonae) and average values of climatic variables [rainfall $(\mathrm{mm})$, maximum and minimum temperature $\left({ }^{\circ} \mathrm{C}\right)$ and relative air humidity $\left.(\mathrm{RH} \%)\right]$ recorded in the study area, Gurupi, Tocantins, Brazil, from January to August 2015.

\begin{tabular}{lcccc}
\hline Rust & Rainfall $(\mathrm{mm})$ & $\mathrm{T}^{\circ} \operatorname{Max}\left({ }^{\circ} \mathrm{C}\right)$ & $\mathrm{T}^{\circ} \operatorname{Min}\left({ }^{\circ} \mathrm{C}\right)$ & $\mathrm{RH}(\%)$ \\
\hline Incidence & $-0,08^{\mathrm{ns}}$ & $0,16^{\mathrm{ns}}$ & $-0,40^{\mathrm{ns}}$ & $-0,27^{\mathrm{ns}}$ \\
Severity & $-0,37^{\mathrm{ns}}$ & $0,46^{\mathrm{ns}}$ & $-0,70^{*}$ & $-0,56^{\mathrm{ns}}$ \\
\hline
\end{tabular}

${ }^{n s}=$ not significant. ${ }^{*}=$ significant according to $F$ test $(P<0,05)$.
Table 2. Coefficient of determination $\left(R^{2}\right)$, standard deviation of initial inoculum $\left(x_{0}\right)$ and rate of disease progress $(r)$ of the logistic, monomolecular and Gompertz models of the severity data of teak rust.

\begin{tabular}{lccc}
\hline Epidemiological models & $R^{2}$ & Initial inoculum $\left(x_{0}\right)$ & Infection rate $(r)$ \\
\hline Logistic & 0,8966 & $4,092 \%$ & 0,0414 \\
Monomolecular & 0,9667 & $-72,495 \%$ & 0,0232 \\
Gompertz & 0,9781 & $1,023 \%$ & 0,0299 \\
\hline
\end{tabular}


minimum temperature. Lower temperatures could prolong leaf wetness, thereby providing favorable conditions for fungal infection (Table 1). Among the tested mathematical models, the Gompertz model best fitted our data of rust disease progress with $R^{2}=0.97$ and the lowest standard deviation of the disease initial inoculum (Table 2).

During the $7^{\text {th }}$ and $90^{\text {th }}$ days of evaluation, rainfall was high. This may have favored the germination of urediniospores to initiate infection in teak leaves. The increase in disease intensity relys not only on rainfall, but also on other climatic variables. Disease incidence was found to be an appropriate variable for monitoring the disease during the first months of assessment. Increases in disease severity occurred even during the dry period from 91 to 196 days after the beginning of the assessment. Thereafter all monitored leaves senesced due to the high rust severity. This showed that there is no need of continuous cycles of rainfall for the rust progress to occur. After the germination of the urediniospores, high temperatures and humidity were sufficient to increase rust severity. During the assessment period, the average monthly maximum temperature reached $38{ }^{\circ} \mathrm{C}$ and the minimum was around $18^{\circ} \mathrm{C}$. This thermal amplitude of around $20^{\circ} \mathrm{C}$, allowed leaf wetness to form and probably favored urediniospore germination, starting leaf infection, and possibly favoring the increase in disease severity. This is further evidenced by the negative correlation between severity and minimum temperature.

Under unfavorable environmental conditions, fungi from the order Uredinales may produce sexual spores named teliospores, which, due to their high resistance, allow the pathogen to surive in such periods (Figueiredo and Carvalho Jr 1995). Given that the sexual stage of $O$. neotectonae has not been found in Brazil, it is possible that other plants serve as inoculum reservoirs during periods that are unfavorable to disease occurrence.

Despite the prospect of great increase in area planted with teak in the tropics, and rust being the most important disease affecting teak, epidemiological studies that could help to better determine the efficiency of the disease's control strategies are still scarce. In the present study, it was possible to conclude that, from the appearance of the first rust symptoms on teak leaves, there was a rapid dissemination and increase in disease severity. Diseased plants were completely defoliated. Given that Gompertz was the best model found to describe rust progress, control measures aimed to reduce the rate of disease progress should be the most effective ones.

\section{ACKNOWLEDGMENTS}

E. U. Leão is grateful to the Council for the Development of Higher Education at Graduate Level (CAPES, Brazil), for the postdoctoral scholarship granted (CAPES-PNPD Process No 007218/2011-24).

\section{REFERENCES}

Bergamin Filho, A. 2011. Curvas de progresso da doença. In: Amorim, L.; Rezende, J.A.M.; Bergamin Filho, A. Manual de Fitopatologia - Principios e Conceitos. São Paulo, Ceres, p. 647-666.

Cabral, P.G.C.; Capucho, A.S.; Pereira, O.L.; Maciel-Zambolim, E.; Freitas, R.L.; Zambolim, L. 2010. First report of teak leaf rust disease caused by Olivea tectonae in Brazil. Australasian Plant Disease Notes, 5: 113-114.

Campbell, C.L.; Madden, L.V. 1990. Introduction to plant disease epidemiology. J. Wiley, New York. 532p.

Figueiredo, M.B.; Carvalho Junior, A.A. 1995. Presença de um auto-inibidor nos teliósporos telióides de Puccinia pampeana e o seu papel na sobrevivência da espécie. Summa Phytopathologica, 21: 200-205.

Gasparotto, L.; Pereira, J.C.R. 2013. A ferrugem da teca no estado do Amazonas. (Comunicado técnico, 101). 1 ed. Embrapa Amazônia Ocidental, Manaus, 4p.

Hackbarth, A.C.; Bonaldo, S.M.; Trento, R.A.; Ribeiro, A.S. 2014. Influência da concentração, do fotoperíodo e da temperatura de armazenamento na germinação de urediniósporos de Olivea tectonae. Bioscience Journal, 30: 340-348.

Pieri, C.; Passador, M.M.; Furtado, E.L.; Carvalho Junior, A.A. 2011. Novas observaçóes sobre a ocorrência da ferrugem da teca (Tectona grandis) no Brasil e revisão taxonômica do patógeno. Summa Phytopathologica, 37: 199-201.

Santos, G.R.; Café-Filho, A.C.; Leão, F.F.; César, M.; Fernandes, L.E. 2005. Progresso do crestamento gomoso e perdas na cultura da melancia. Horticultura Brasileira, 23: 228-232.

Thorntwaite, C.W. 1948. An approach toward a rational classification of climate. Geographical Review, 1: 55-94.

Vale, F.X.R.; Jesus Junior, W.C.; Zambolim L. 2004. Epidemiologia aplicada ao manejo de doenças de plantas. Perfil, Belo Horizonte, 532p.

Received: 21/11/2016

Accepted: 26/05/2017 